\title{
Intellectual Capital: A Meta-Analysis of Its Dimensions, Antecedents and Consequences
}

Hasan Rangreez ${ }^{1}$ Associate Professor, Faculty of Management, Kharazmi University, Tehran, Iran.

Abdossamad Azizpour Lindi² Ph.D. Student, Faculty of Management, Kharazmi University, Tehran, Iran. (Corresponding Author)

Fariba Shahidzadeh ${ }^{3}$ Ph.D. Student, Faculty of Management, Kharazmi University, Tehran, Iran.

\begin{abstract}
Intellectual capital is considered necessary for today's organizations. This paper examines and identifies the dimensions, antecedents and processes of intellectual capital by using meta-analysis approach. The statistical population included 18 Farsi articles, masters' theses and doctoral dissertations in the field of intellectual capital, all of which had applied quantitative research method and were defended and published between 2008 and 2019. Using non-targeted sampling method, articles were selected and analyzed through meta-analysis process. Results show that the variables of organizational agility, knowledge storage, knowledge acquisition, competitive advantage, knowledge sharing, knowledge application, knowledge management and knowledge learning have the highest impact size and the variables of profitability, human capital, return on equity, structural capital, productivity and relationship capital have the least effect on intellectual capital. The findings of this research can work as a milestone for more investigations in intellectual capital.
\end{abstract}

Keywords: Intellectual Capital, Meta-analysis, Dimensions, Antecedents, Consequences.

1. rangriz@khu.ac.ir

2. a.s.azizpour.1@ut.ac.ir

3. f.shahidzade@ut.ac.ir 


\section{مقدمه}

از جمله مفاهيمى كه يويايى محيط و مديريت سازمانها را تحت يوشش قرار مىدهد، مديريت سرمايه فكرى' است. به دليل تحولهاى يىدريى و جابهجايى قدرت در عصر حاضر، ڤّ از رواج موضوع مهندسى مجدد در دهه •191 و مديريت كيفيت فراگير در دهه • 199 به عنوان يديدهاى مههم، موضوع مديريت سرمايه فكرى و دارايىهاى ناملموس سازمانها افق مديريت را تحت تاثير

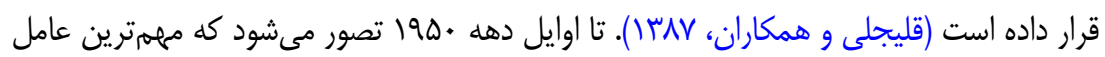
و ريشه عقبماندكى كشورهاى درحالتوسعه كمبود سرمايه مالى و فيزيكى است (عزيزيور، عوسا). करें اما امروزه اين حقيقت مسلّم است كه تزريق مقادير متناهى از سرمايه فيزيكى و مالى بـ به اين

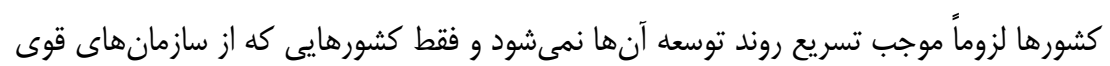
و نهادهاى ادارى كارامد، و در عين حال، از سرمايه انسانى كاراو متخصص برخورداردارند، مى توتوانند سرمايه فيزيكى و مالى خود را به نحو مناسب جذب كنند و در تسريع روند رشد و توسعه موفق

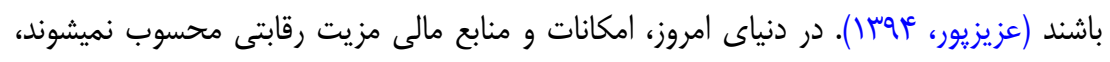

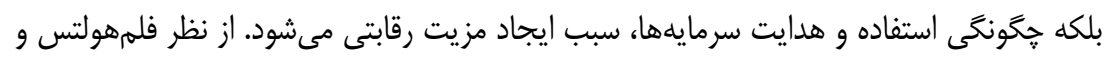

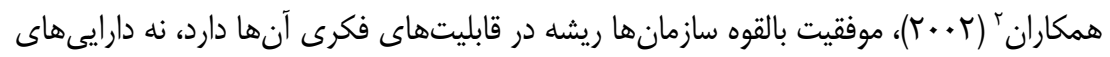

در وضعيت كنونى كه ناطمينانى افزايش مىيابد و اطلاعات يك نيازمندى مهم براى مديريت

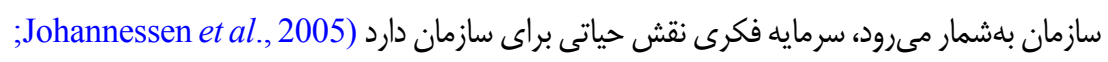
.(Chen et al., 2005; Herremans \& Isaac, 2004; Usoff et al., 2002; Klaila \& Hall, 2000

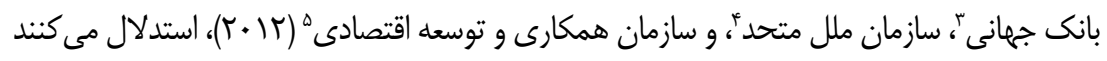

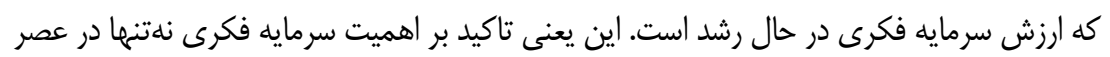
حاضر، بلكه در آينده نيز يك ارزش براى سازمانهاست (عزيزيور، عوسا). با ورود مفهوم سرمايه

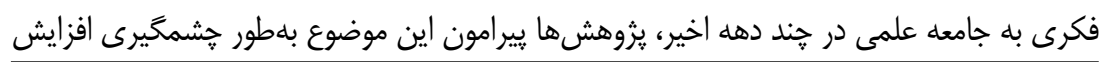

1. Intellectual Capital Management

2. Flamholtz et al.

3. World Bank

4. United Nations (UN)

5. Organization for Economic Co-operation and Development (OECD) 
يافته است، بلطورى كه جامعه علمى با اطلاعات وسيع و انباشتهاى در اين زمينه روبادرو شده است.

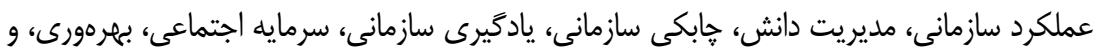

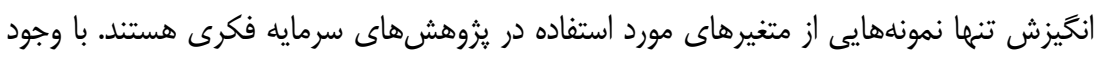
كثرت يزوهشهاى حوزهٔ سرمايه فكرى در سال هاى اخير، اجماع نظرى در مورد عوامل موثر بر سرمايه

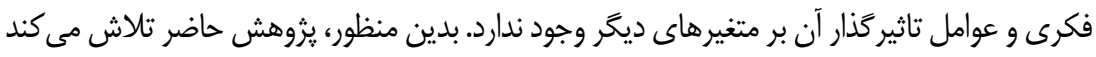

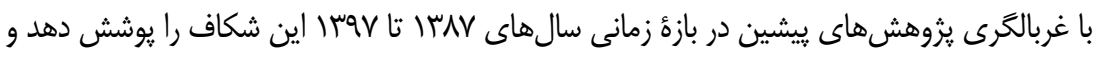

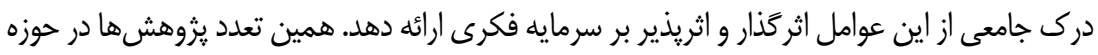

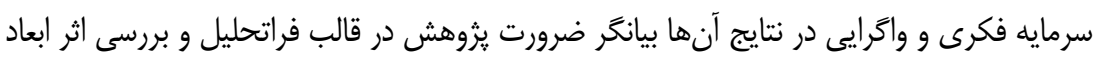

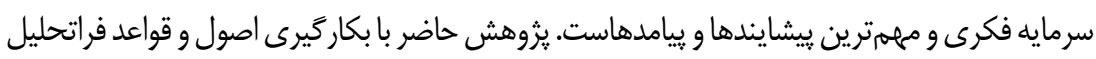
به بررسى يزوهش هاى انجامًر فته در حوزه سرمايه فكرى مى يردازد و به دنبال حل تناقضات و رسيدن

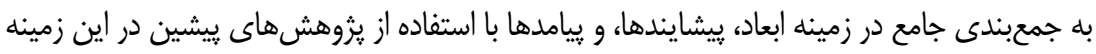

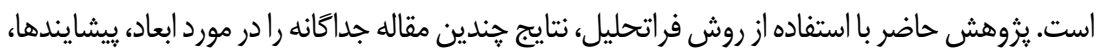

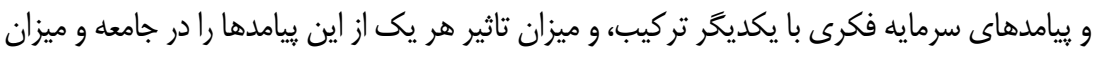

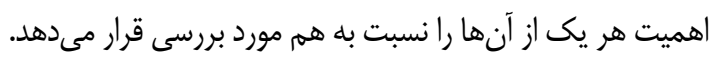

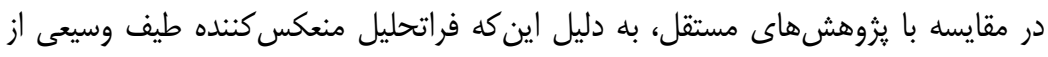

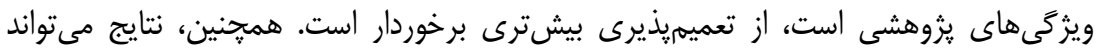

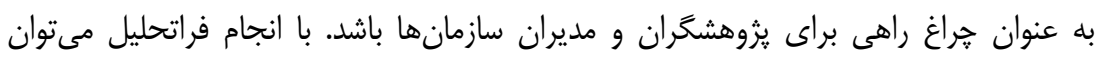

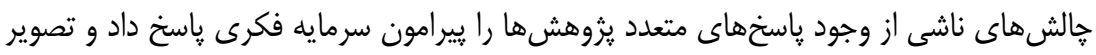

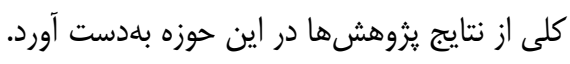

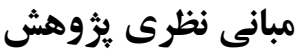

قرن بيستويكم، قرن اقتصاد دانشمحور مبتنى بر سرمايه فكرى و عصر حاكميت دانش

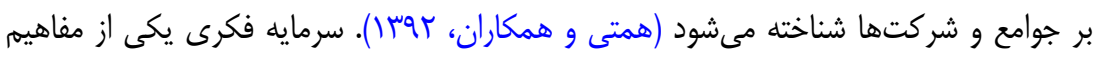

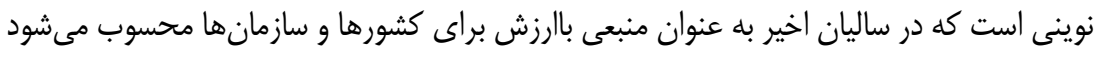

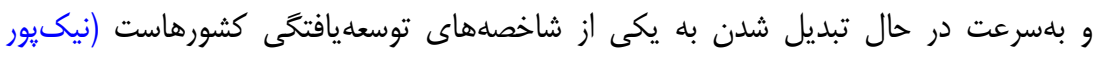

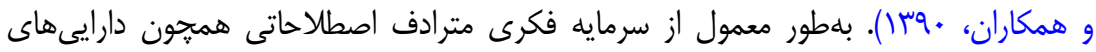
نامشهود يا دار ايىهاى دانشى ياد مىشود. رهبرانى كه اهميت يادكيرى را درك مى كنند، تلاشهاى راهبردى خود را از مديريت دارايىهاى مشهود به مديريت دارايىهاى نامشهود همجيون سرمايه 
فكرى معطوف مى كنند (Leliaert et al., 2003). مفهوم سرمايه فكرى در تشريح راهبردى و درى عملى قابليتهاى كليدى سازمانها كسترش مىيابد. مفهوم نظرى سرمايه فكرى

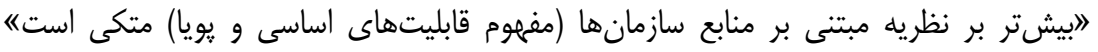

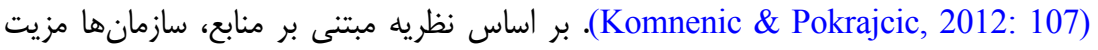

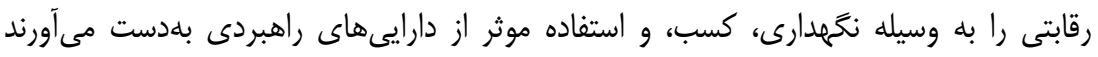

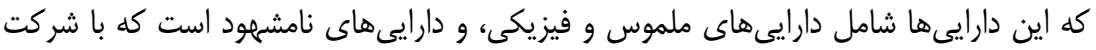

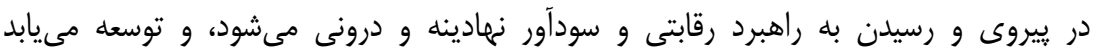

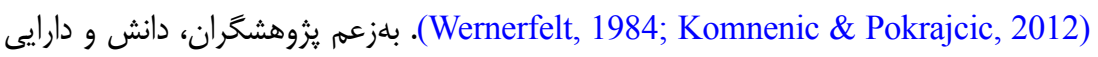

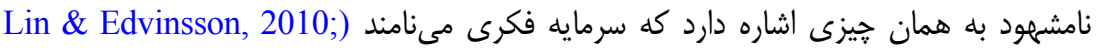
.(Stewart, 2010 مولياتينى و همكاران' (19 +(T)، بيان مى كنند كه سرمايه فكرى اشاره به سرمايههاى فيزيكى و

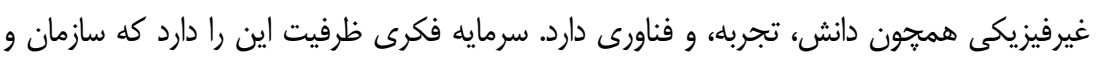

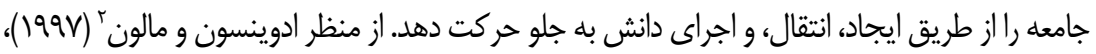

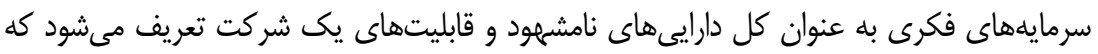

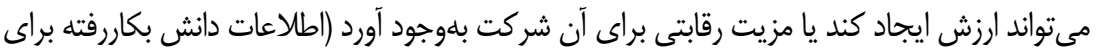

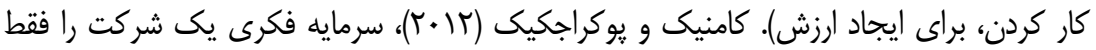

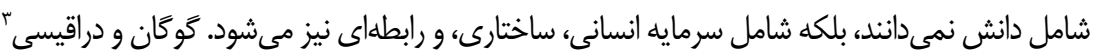

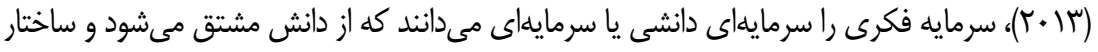

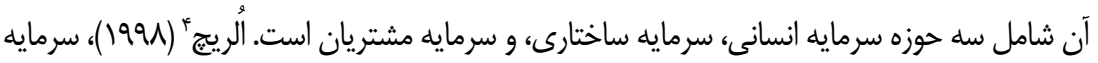

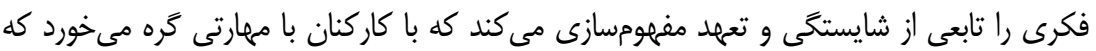

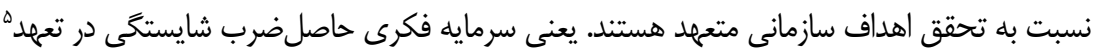
است. در اين تعريف، سطح سرمايه فكرى سازمان را مجموع سرمايه در سطح فردى مشخص مى سازد. سازمان همكارى و توسعه اقتصادى (1999)، سرمايه فكرى را با ارزش اقتصادى انسان و ساختار موجود در سازمان به عنوان دو داريى نامشهود سازمانى تعريف مى كند. در اين تعريف، انسان مىتواند شامل

\footnotetext{
1. Mulyatini et al.

2. Edvinsson \& Malone

3. Gogan \& Draghici

4. Ulrich

5. Intellectual Capital $=$ Competency $\times$ Commitment
} 
همه افراد اعم مشتريان، كاركنان، تامين كنندًان، رقبا، يا مقامات دولتى باشد كه بلنوعى با سازمان در

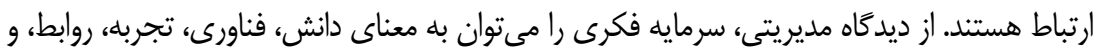

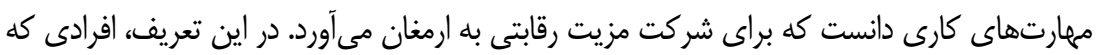
سازمان را تشكيل مى دهند، ابعاد ساختارى سازمان و تمامى ارتباطات سازمان را مورد مطالعه قرار مى دهائ.

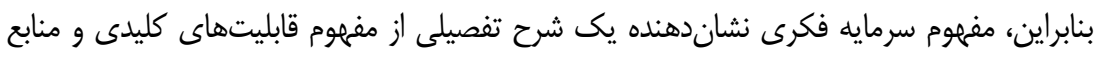
راهبردى به عنوان محور سود در ديدكاه مبتنى بر منابع موجود و دانش در سازمان است كه پاياياى براى

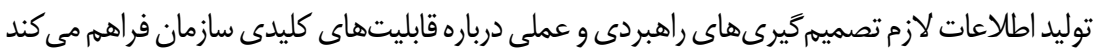

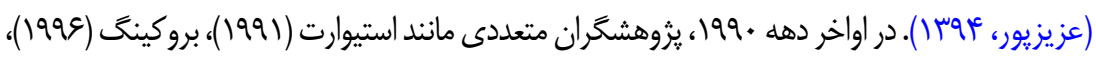

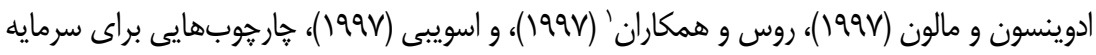

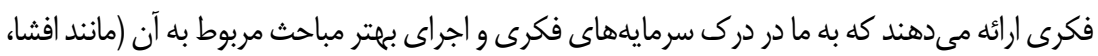

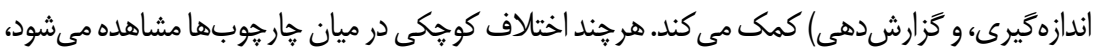

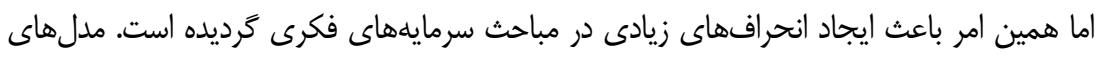
ارائهشده در اين خصوص به اختصار در جدول (ا () معرفى مئشوند.

\section{جدول 1: مدلهاى سرمايه فكرى}

\begin{tabular}{|c|c|}
\hline اجزاى سرمايه فكرى و مولفهها & يديد آورند \\
\hline سرمايه انسانى، سرمايه ساختارى، و سرمايه مشترى & استيوارت (1991) \\
\hline دارايى هاى بازارى، مالكيت معنوى، افراد، و زيرساخت & بروكينگ (1994) \\
\hline 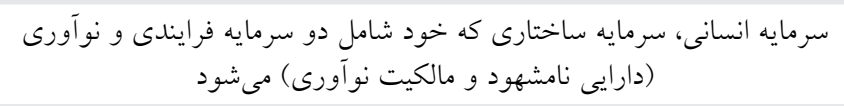 & 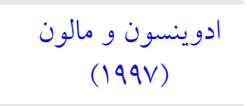 \\
\hline 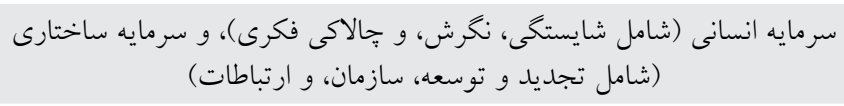 & $\begin{array}{l}\text { روس و همكاران } \\
\quad(199 V)\end{array}$ \\
\hline 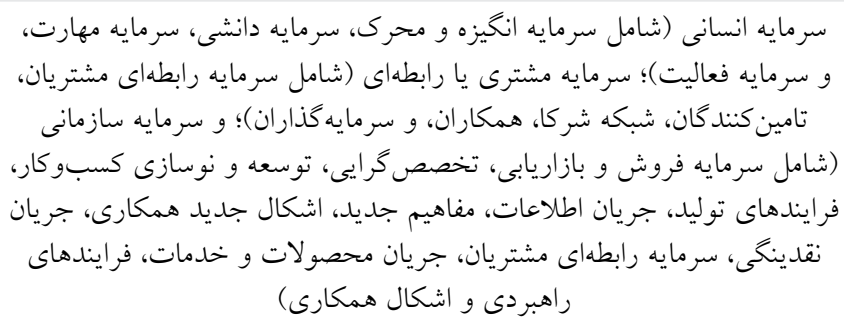 & 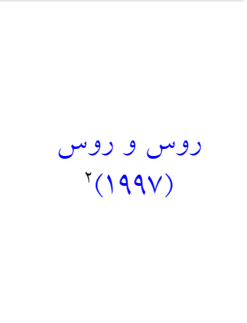 \\
\hline
\end{tabular}

1. Roos et al.

2. Roos \& Roos 


\begin{tabular}{|c|c|}
\hline اجزاى سرمايه فكرى و مولفهها & \\
\hline 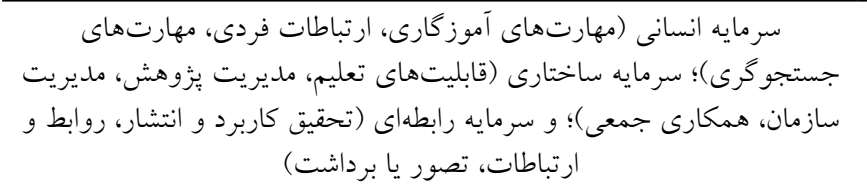 & ـا' تورز \\
\hline 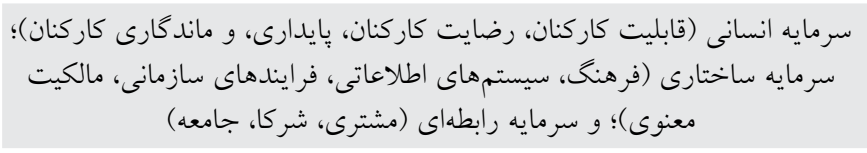 & $r(r \cdots d)^{4}$ \\
\hline 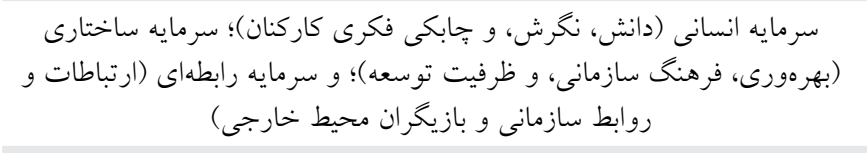 & 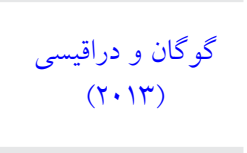 \\
\hline 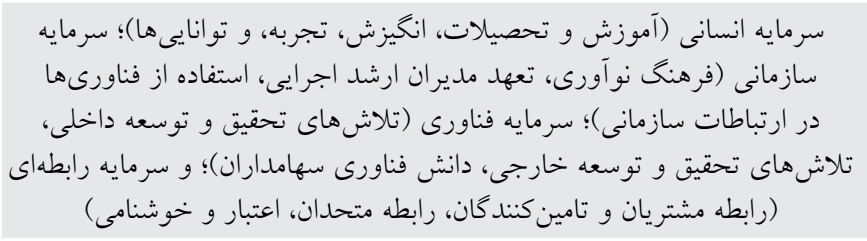 & مارتين دى كاسترو و \\
\hline 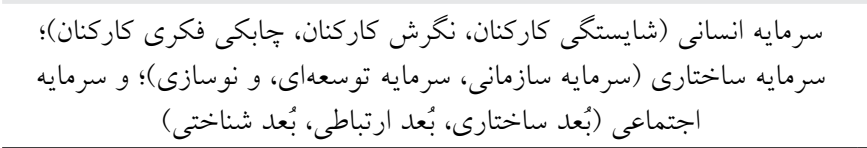 & 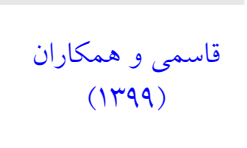 \\
\hline
\end{tabular}

\section{شباهت موجود در تعاريف و اجزاى مدل هاى سرمايههاى فكرى}

هنگَامى كه ادبيات مربوط به سرمايه فكرى بررسى مىشود، به نظر مىرسد بيشتر مدلهاى

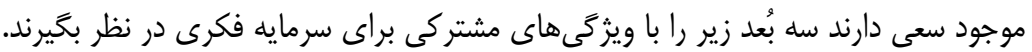
بُعد انسانى: اين بعد يكى از مهرمترين دارايىهاى دانشى و منبع خلاقيت در سازمان است كه توسط كار كنان به نمايش گذاشته مى شود. همين دانش ضمنى كاركنان سازمان از عوامل حياتى اثرگذار بر عملكرد سازمان است. بايد اين نكته را مد نظر داشت كه مالكيت اين نوع سرمايه در اختيار سازمانها نيست و با خروج افراد از سازمان حافظه سازمانى از دست مىرود، كه اين خود يك نوع 
تهديد سازمانى بلشمار مىرود. شولتز' (1991)، و زاكمن و همكارانَ (1919)، سرمايه انسانى را

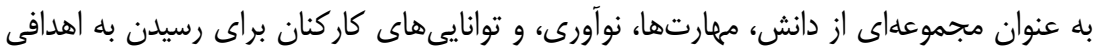

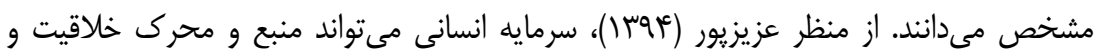

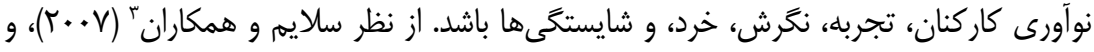

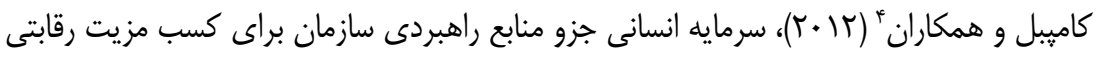
در محيط در حال تغيير و متلاطه امروزى است. سرمايه انسانى لامجموع مهارت، شايستخى، دانش،

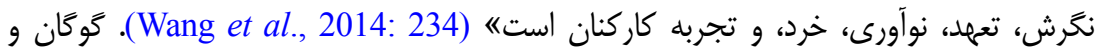

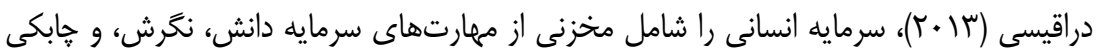

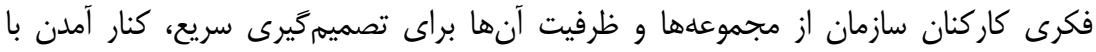
مشكلات، و ايجاد روابط بين فردى مناسب تعريف مى كنند.

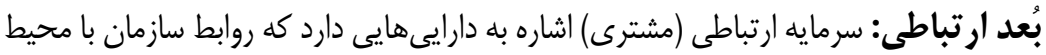

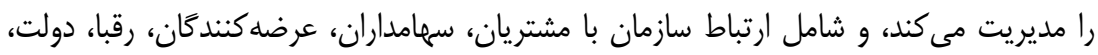

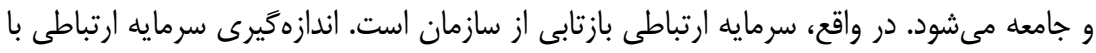

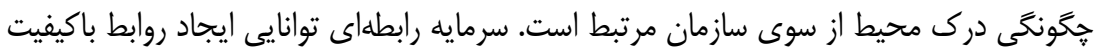

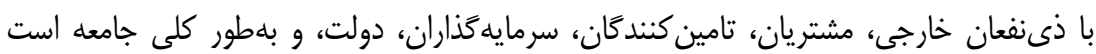

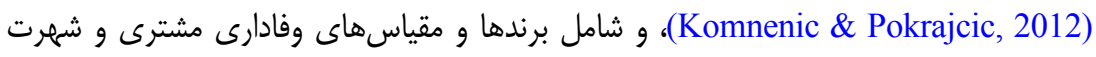
شر كت و عرضه كنندًان و سيستمهاى بازخورد مشترى است. سرمايه مشترى يا رابطهاى با مد نظر

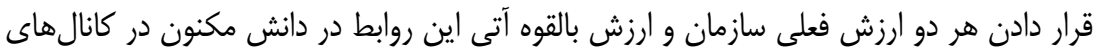

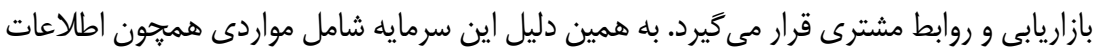
و روابط با مشترى، علايم و قراردادهاى تجارى، و سهم بازار مى شودد (Bontis et al., 2000).

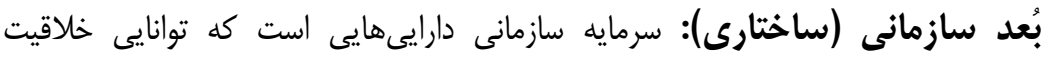

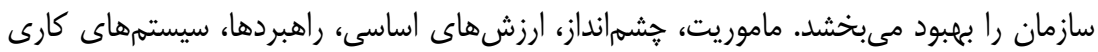

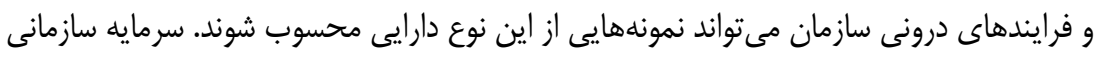

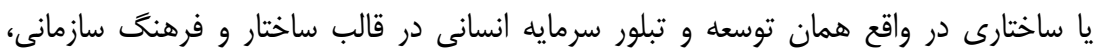
دانش مدون، فرايندهاى كسبوكار، نوآورى، مالكيت معنوى و ساختار مالى و فيزيكى شركت

1. Schultz

2. Sackman et al.

3. Seleim et al.

4. Campbell et al. 
است (Komnenic \& Pokrajcic, 2012). در واقع راهبردها، خطمشىها، دستورالعملها و

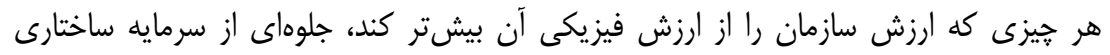

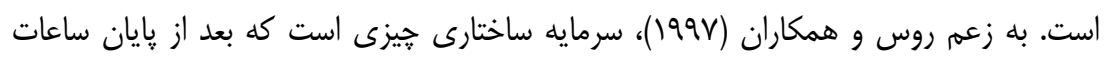

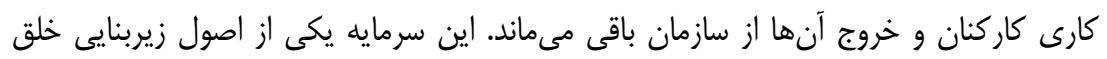

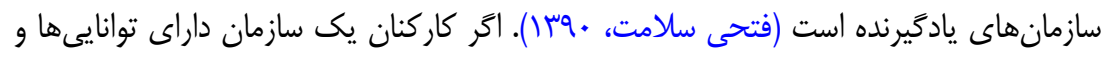

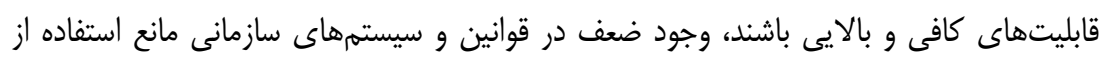

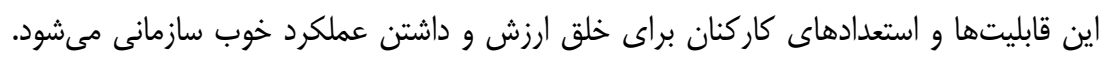

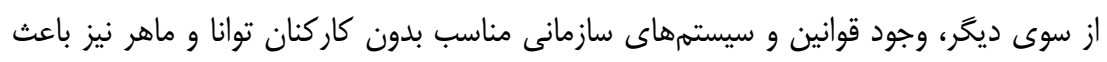

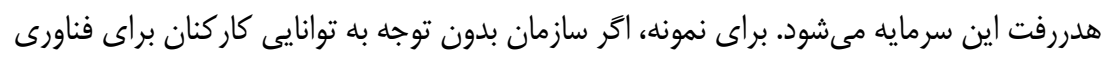

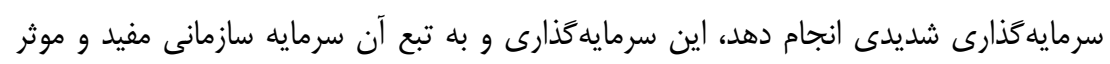

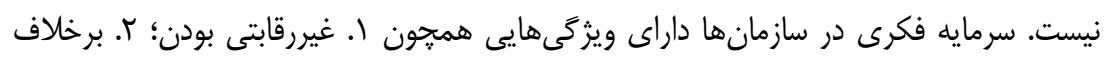

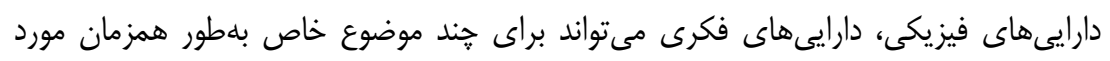

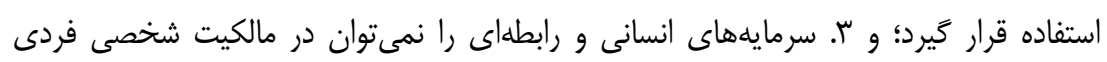

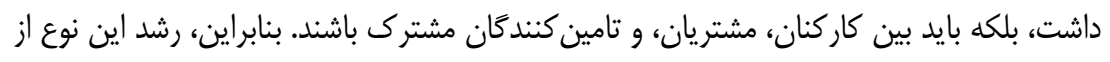

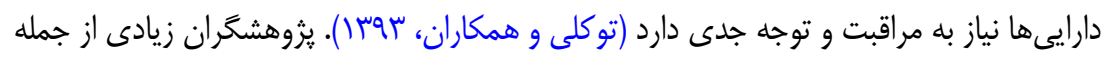

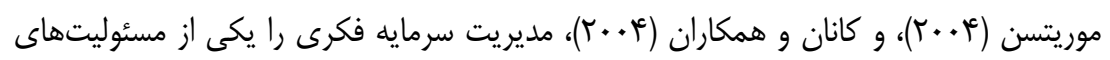

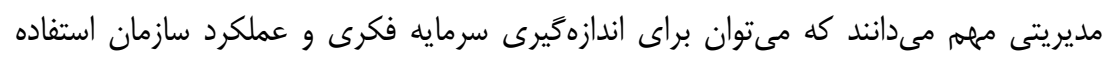

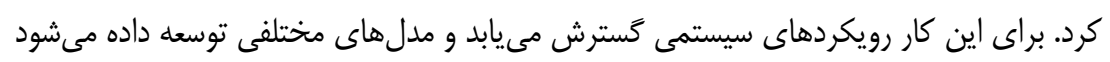
.(Litschka et al., 2006)

\section{روش}

فراتحليل، تحليل تحليلها يا تحليل مجموعهاى از نتايج يزوهشهاى جداكانه به منظور تركيب

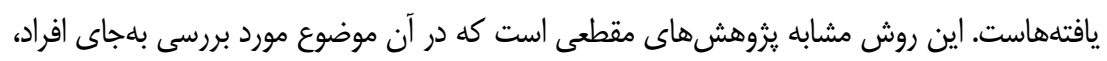
نتايج يزوهشهاست. فراتحليل فقط براى يثوهشهاى كمّى كاربرد دارد (Pigott, 2012).

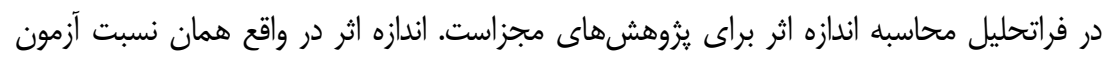

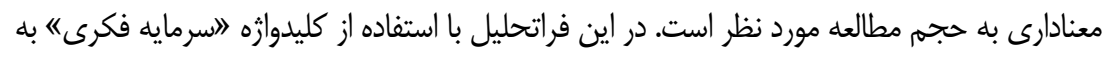

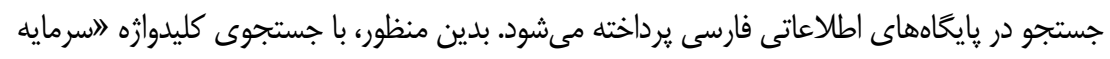

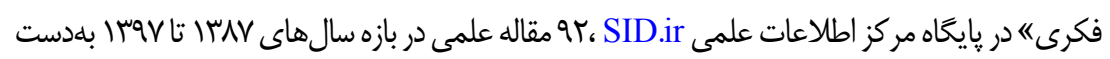


مى آيد. همجنين، براى جامعيت بيشتر يثوهش در بايڤاه مجلات تخصصى نور (noormags.ir)، نيز در بخش جستجوى ييشرفته عبارت "اسرمايه فكرى" در بين مجلههاى علمى ـ يزوهشى فارسىزبان

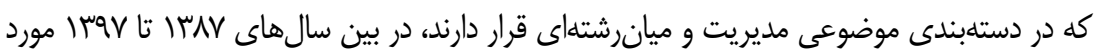
جستجو قرار مى كيرد كه در نهايت بو مقاله شناسايى مى شود. دليل جستجو در اين بازه زمانى، اقبال

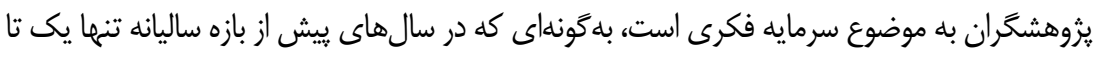

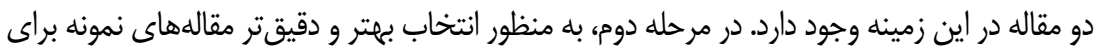

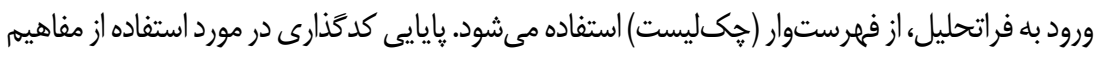

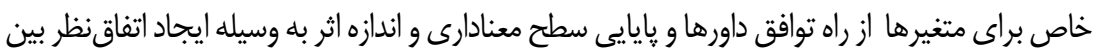

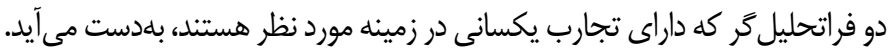

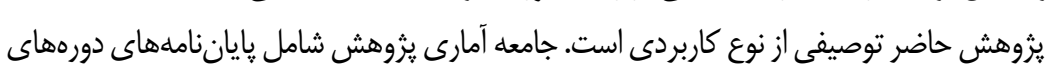
تحصيلات تكميلى كارشناسى ارشد و دكترى درون كشور، و مقالههاى منتشرشده در نشريههاى علمى ترى

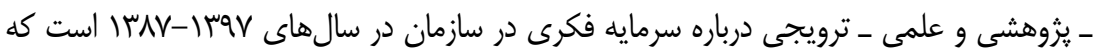

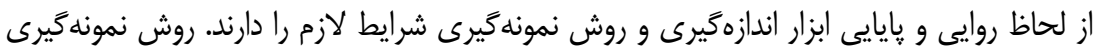

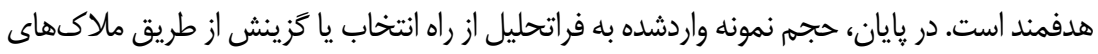

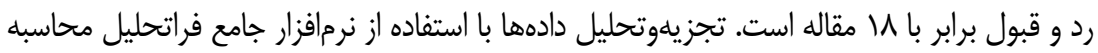
اندازه اثر (CMA2) انجام مىشود. همجنين در اين يزوهش، براى سنجش سوءگيرى انتشار، تعيين

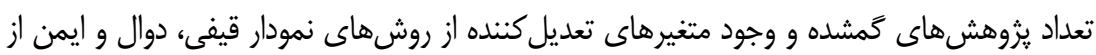

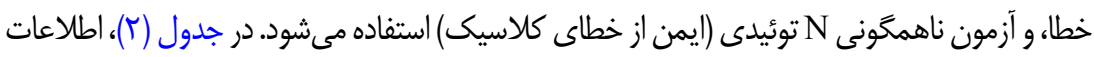

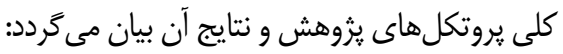

\begin{tabular}{|c|c|c|}
\hline بايخاه اطلاعاتى نور & SID & فيلترهاى جستجو \\
\hline $1 \% \wedge V-1 Y q V$ & $1 \% \wedge V-1 \% q V$ & سال ״ابٍ \\
\hline كمّى & كمّى & نوع مقالهها \\
\hline علمى - يزوهشى & علمى - تيزوهشى - ترويجى & اعتبار مقالهها \\
\hline سرمايه فكرى & 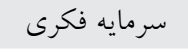 & عبارت جستجو در عنوان و كليدوازهها \\
\hline ar & 94 & تعداد نتيجه \\
\hline
\end{tabular}

1. SID.ir 


\section{تجزيلوتحليل يافتهها}

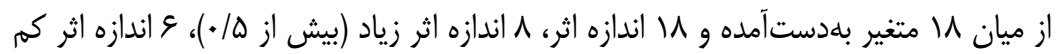

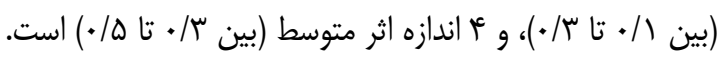

جدول זّ: اندازه اثر ابعاد سرمايه فكرى

\begin{tabular}{|c|c|c|c|c|c|c|}
\hline اندازه اثر & سطح معنادارى & Z-value & كران بالا & كران يايين & ابعاد & رديف \\
\hline$\cdot / \pi 10$ & $\cdot / \cdots$ & $Y / D \wedge 9$ & $\cdot / r \cdot r$ & $\cdot / M Y$ & سرمايه انسانى & 1 \\
\hline$\cdot$ / TAY & $\cdot / \cdots$ & $\Delta / 9 \wedge Y$ & $\cdot / r q 4$ & ./IVG & سرمايه رابطهاى & r \\
\hline$\cdot / T H A$ & $\cdot / \cdots$ & Q/ & תחس/. & $\cdot / 109$ & سرمايه ساختارى & r \\
\hline
\end{tabular}

جدول ثا: بيامدهاى سرمايه فكرى

\begin{tabular}{|c|c|c|c|c|c|c|}
\hline \multicolumn{7}{|c|}{ جدول ثا: ييامدهاى سرمايه فكرى } \\
\hline 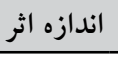 & سطح معنادارى & $\mathrm{Z}$ - value & كران بالا & كران يايين & 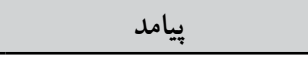 & رديف \\
\hline$\cdot / N r^{4}$ & $\cdot \cdots$ & $I V / T \Lambda$ & $\cdot$ /VAr & $\cdot / 9 \Lambda \Lambda$ & "جابكى سازمانى & 1 \\
\hline$\cdot / 9 \cdot 1$ & $\cdot / \cdots$ & $9 / 199$ & •/9ヘr & $\cdot / 0 \cdot r$ & مزيت رقابتى & r \\
\hline$\cdot / r V V$ & $\cdot \cdots$ & N/NHV & $\cdot / 4 Q$ & $\cdot / 799$ & عملكرد مالى و اقتصادى & r \\
\hline • MAT & $\cdot / \cdots$ & $\mid 1 / 491$ & $\cdot / r q V$ & $\cdot / T \wedge V$ & نسبت ارزش بازار به دفترى & $r$ \\
\hline$\cdot / 1 \vee q$ & $\cdot \cdots$ & Q/vq. & $\cdot / r \mu q$ & $\cdot / 111$ & سودآورى & 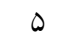 \\
\hline$\cdot /$ TYY & $\cdot / \cdots$ & $9 / 941$ & $\cdot / T r V$ & $\cdot / r \cdot 1$ & بازده حقوق صاحبان سهام & 4 \\
\hline$\cdot / 499$ & $\cdot \cdots$ & $9 / 9 k \mu$ & $\cdot / \Delta \wedge$ & $\cdot / 4 \cdot 9$ & عملكرد سازمانى & $\checkmark$ \\
\hline •/ror & $\cdot \cdots$ & $1 / 44$ & $\cdot / \mu \cdot \wedge$ &.$/ 199$ & بهري & $\wedge$ \\
\hline
\end{tabular}

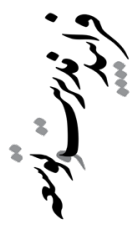

جدول ه: ييشايندهاى سرمايه فكرى

\begin{tabular}{|c|c|c|c|c|c|c|}
\hline اندازه اثر & سطح معنادارى & $Z$ - value & كران بالا & كران بايين & بيشايند & رديف \\
\hline - /OFT & $\cdot \cdots$ & $|9 / \pi|$. & - /09T & $\cdot / 4 \wedge 9$ & مديريت دانش & 1 \\
\hline$\cdot / 4 \wedge \Delta$ & $\cdot \cdots$ & $1 / 990$ & $\cdot 1099$ & - rar & خلق دانش & r \\
\hline.$/ 91 \mathrm{~V}$ & $\cdot / \cdots$ & $11 / 9 T \Delta$ & $\cdot / 9 \wedge 0$ & - $/ 0$ rq & كسب دانش & $r$ \\
\hline$\cdot / 0 \cdot r$ & $\cdot \cdots$ & $9 / 14 \wedge$ & $\cdot / \Delta \wedge \Delta$ & $\cdot / 4 \cdot 1$ & يادكيرى دانش & $r$ \\
\hline$\cdot / 09 \Lambda$ & $\cdot \cdots$ & $1 \cdot 191$ & . IGKY & •/YAT & تسهيم دانش & 0 \\
\hline - /DQR & $\cdot \cdots$ & $1 \cdot / \pi Y \Lambda$ &.$/ 9 \mu$. &.$/ 494$ & كاربرد دانش & 9 \\
\hline .194 & $\cdot \cdots$ & $|r /| Y \wedge$ & - NYY & $\cdot / \Delta \wedge \Lambda$ & ذخيرهسازى دانش & V \\
\hline
\end{tabular}




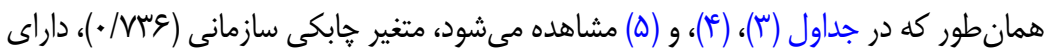

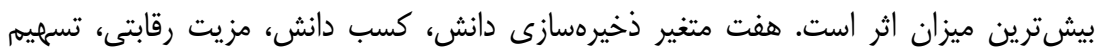

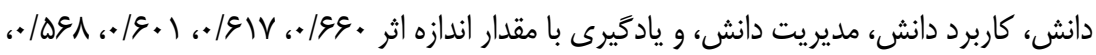

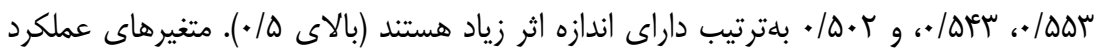

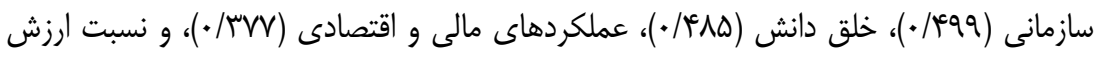

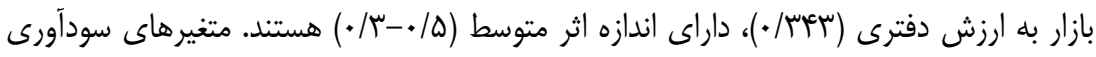

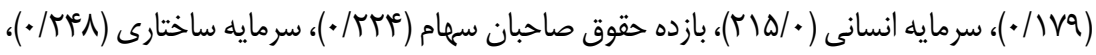

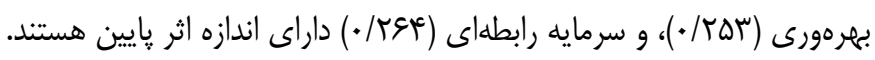

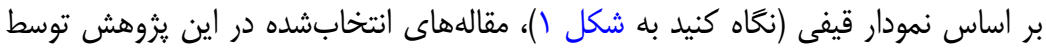

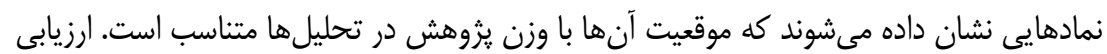

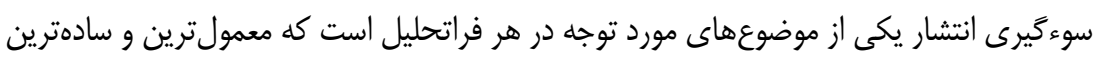

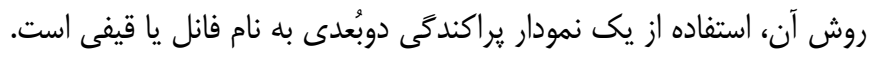

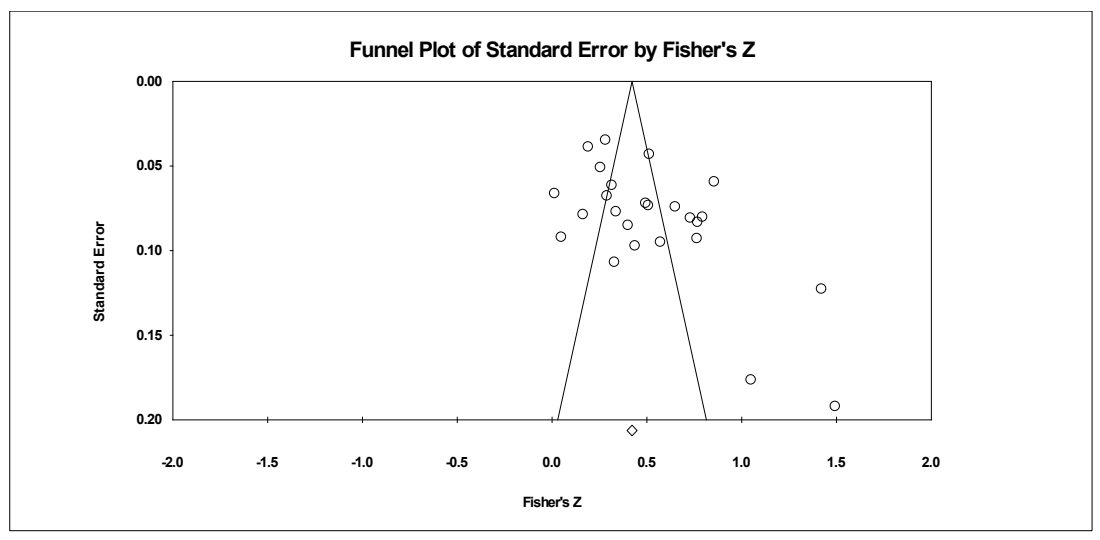

شكل 1: نمودار فانل (قيفى) يزوهشهاى سرمايه فكرى

يزوهشهاى باكيفيتتر، خطاى كمترى دارند. در نمودار قيفى، وقتى از بايين به سمت بالا

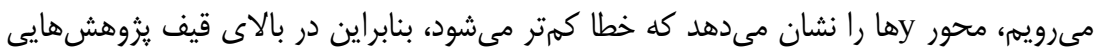

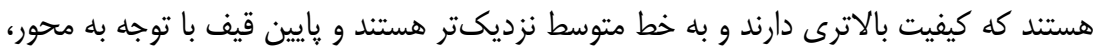

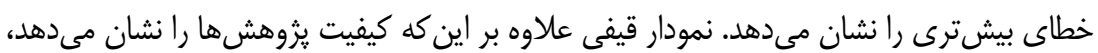


بيانكر بود يا نبود سوءيرى نيز هست. اخر سوءيرى نباشد، يثوهش ها بايد نزديك خط وسط محور

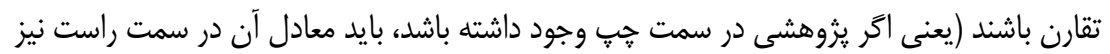

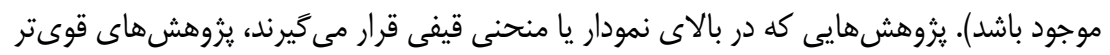

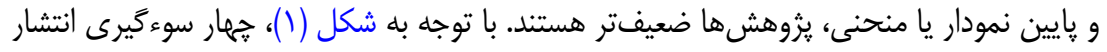

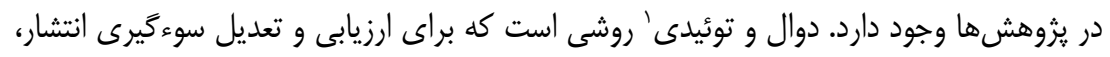

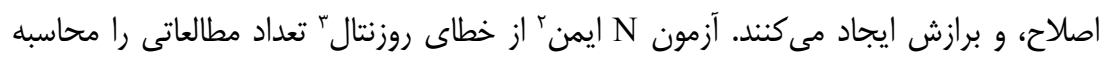

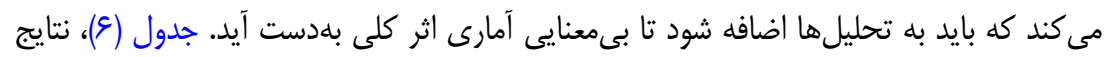

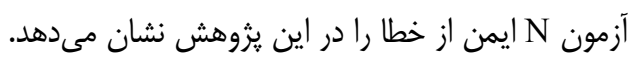

جدول \&: اصلاح و برازش دوال و توئيدى

\begin{tabular}{|c|c|}
\hline MT/VAY & مقدار Z براى ثيزوهش هاى مشاهدهده \\
\hline · & مقدار P براى يُزوهش هاى مشاهدهده \\
\hline$\cdot 1 \cdot 0$ & آلفا \\
\hline r & باقيمانده (دنباله) \\
\hline $1 / 090$ & 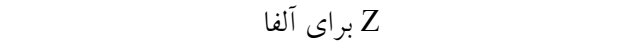 \\
\hline rQ & تعداد يُزوهش هاى مشاهدهشده \\
\hline $99 \mathrm{~V}$. & تعداد يزووهشهاى گمشدهاى كه مقدار P را به آلفا مىرساند \\
\hline
\end{tabular}

جدول Y: محاسبههاى N ايمن از خطا (تعداد ناكامل بع خطر) كلاسيك

\begin{tabular}{|c|c|c|c|c|c|c|c|}
\hline Q مقدار Q & \multicolumn{3}{|c|}{ اثرهاى تصادفى } & \multicolumn{3}{|c|}{ اثرهاى ثابت } & \\
\hline تعداد يزوهش هورد نياز & كران بالا & كران & تخطهاى تخمين & كران بالا & كران يايين & تخطهاى تخمين & \\
\hline rNI/FYO & $\cdot$ /DST & - raq & $\cdot / \mathcal{F} \wedge \mathcal{F}$ & D/AT & $\cdot /$ TVQ & $\cdot / r q \wedge$ & ارزش مشاهدهها \\
\hline$V \cdot V / 90 Y$ & . MAY & - /rTa & $\cdot / \mu k$ & $\cdot / M Y A$ & $\cdot \pi \cdot r$ & - MTS & رزش تعديلشده \\
\hline
\end{tabular}

با توجه به دادههاى جدول (V)، بايد •99V يُوهش ديخر بررسى شود تا مقدار P دو دامنه

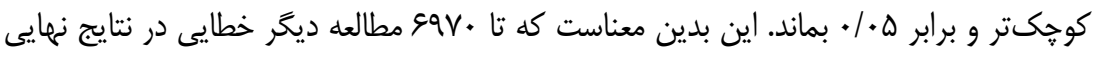

1. Duval and Tweedie's Trim

2. Fail- Safe N

3. Rosenthal 
و تحليلها رخ نمىدهد. براى بررسى همكونى يا ناهمگونى اندازه اثرها آزمون كوكرام (Q)

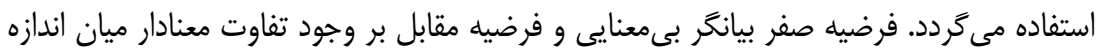

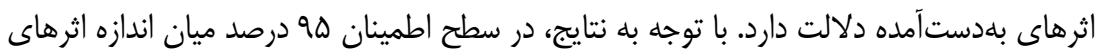

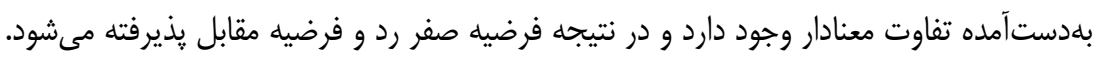

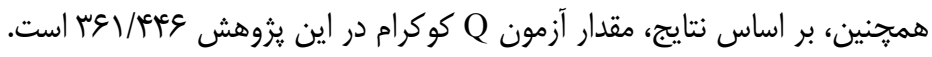

\section{آزمون}

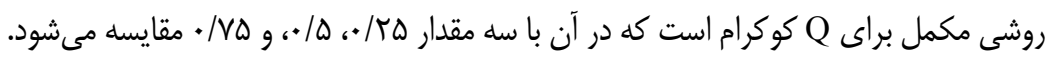

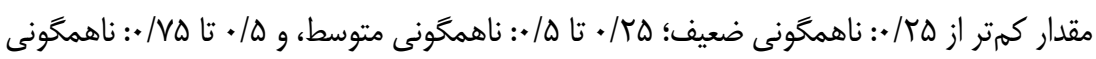

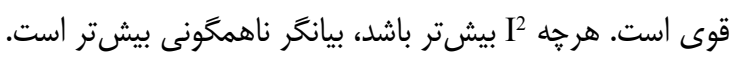

\section{آزمون تاو (همبستگى بين ثئوهشها)}

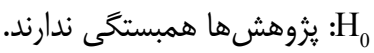

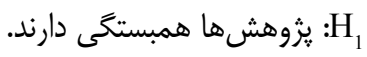
$. R>75, R<75>0 / 5$, $\mathrm{R}<0 / 5>0 / 33 \leqq R<=0 / 33$

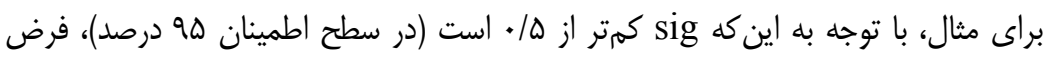

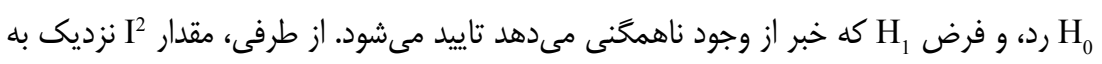

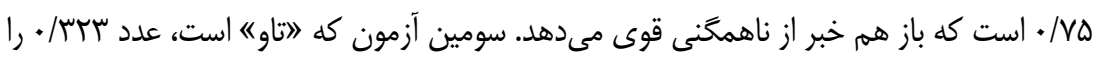

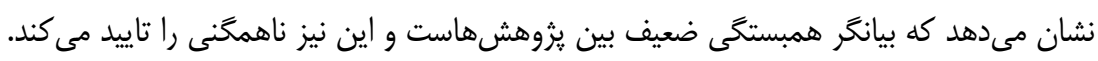

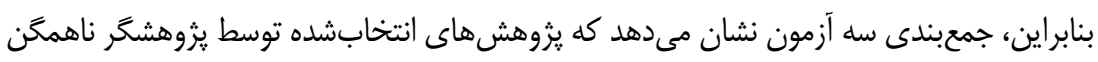

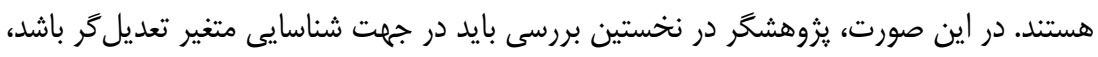

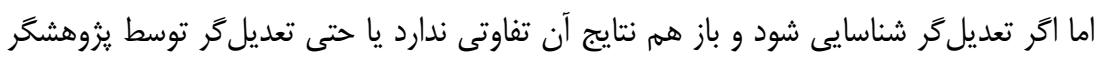
شناسايى نشود، بهترين مدل، اثرهاى تصادفى است.

\section{بحث و نتيجه كيرى}

يروهش حاضر با هدف مشخص كردن مهمترين و تاثير تذارترين ابعاد، ييشايندها، و ييامدهاى

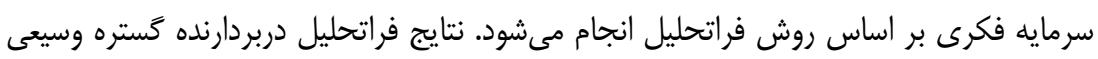

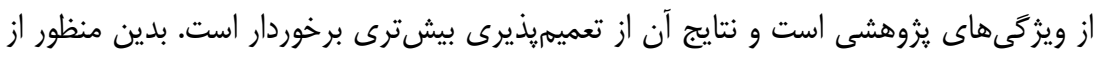


جامعه آمارى شامل پايان نامههاى كارشناسى ارشد، دكترى، و مقالههاى خابشده در مجلههاى علمى ـ يزوهشى و علمى ـ ترويجى با موضوع سرمايه فكرى ل1 ا مقاله به عنوان نمونه اثر مولفهها،

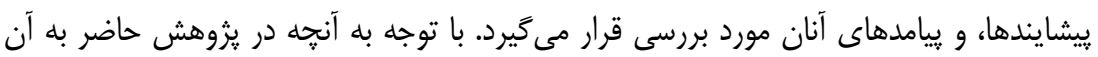

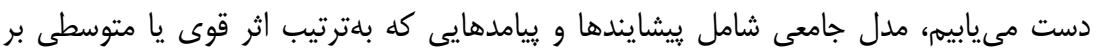

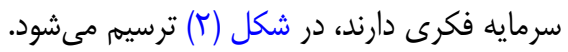

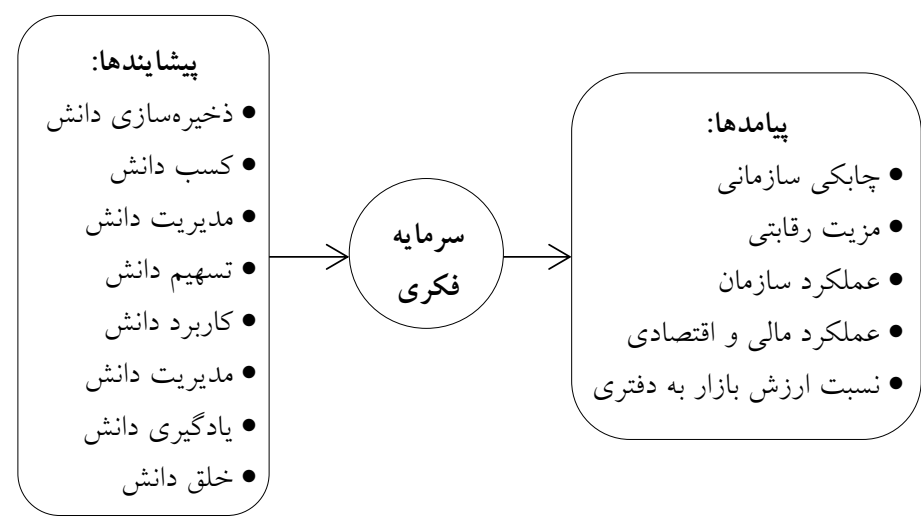

شكل r: بيشايندها و ييامدهاى سرمايه فكرى بر اساس نتايج فراتركيب

با توجه به نتايج بهدستآمده از خروجى نرمافزار، جابكى بيشترين اثر را به عنوان ييامد بر

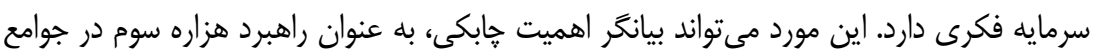

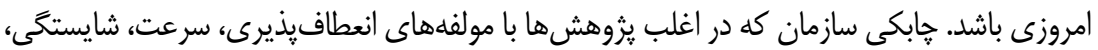

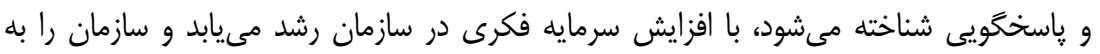

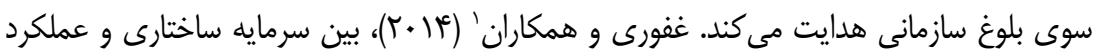
سازمان رابطهاى متصور نيستند و اثر سرمايههاى رابطهاى و انسانى راعملكرد سازمان متوسط ارزيابى

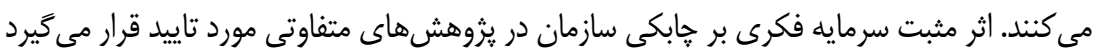

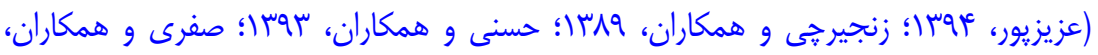

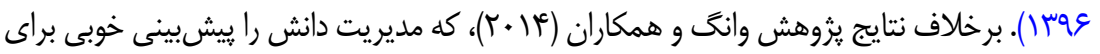

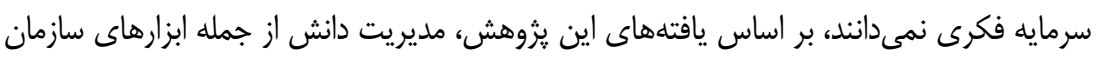

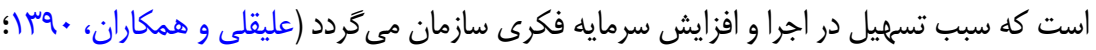

1. Ghafuri et al. 
علامه و شيخ ابومسعودى، זqجا؛ سيدنقوى و همكاران، اجسا؛ حسنوى و همكاران، هوسا؛ و ب.Hsu \& Sabherwal, 2012; Indiyati, 2016; Shih et al., 2010; Zhou \& Fink, 2003 وجود رقابت شديد و منابع كمياب، كسب مزيت رقابتى براى سازمانهاى امروزى از ضرورت ويزهاى

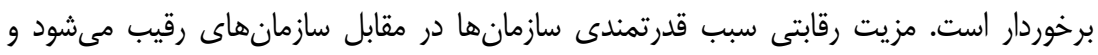

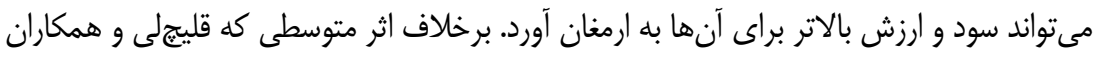
(INAV) بهدستآمده سرمايه فكرى اثرى قوى بر كسب مزيت رقابتى سازمانها دارد. عليقلى و همكاران

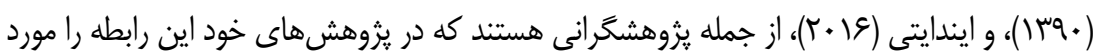

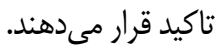
بر اساس نتايج، مباحث عملكردى اعم از موضوعهاى عملكرد سازمانى، عملكرد مالى و اقتصادى،

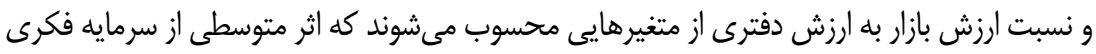

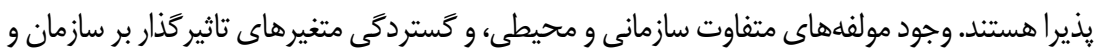

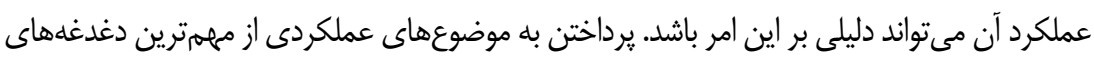

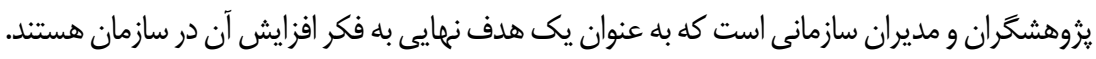

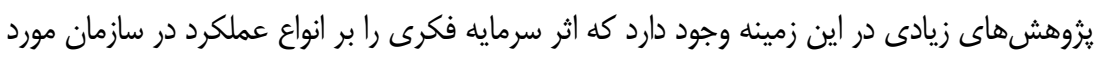

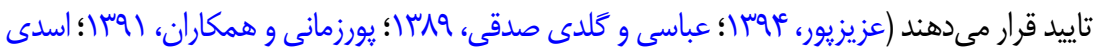

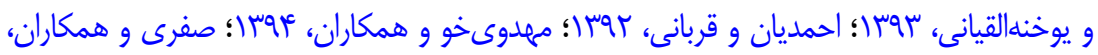
عوسا؛ و Mention \& Bontis, 2013; Wang et al., 2014; Khalique et al., 2013 (Y). بر קايه

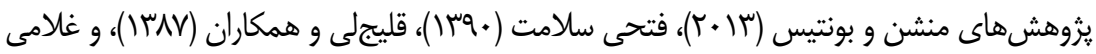

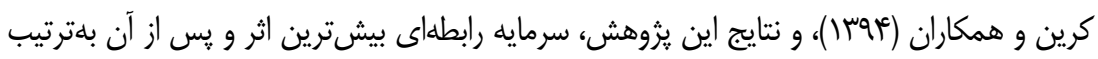

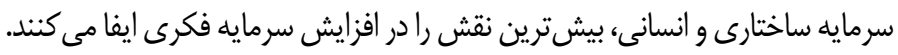

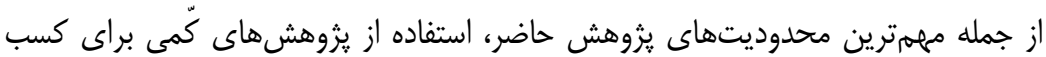

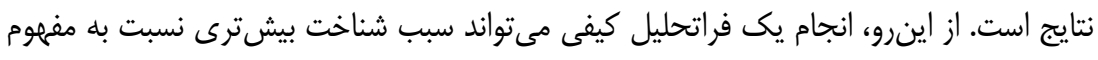

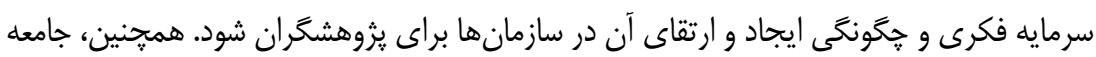

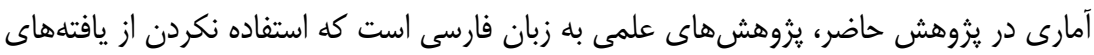

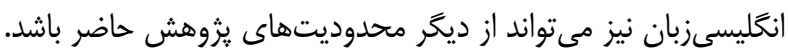

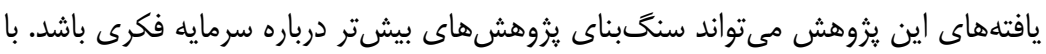

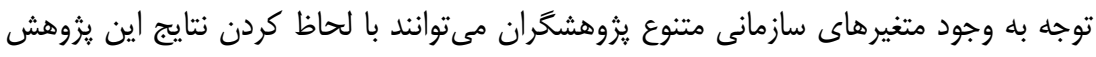


و ميزان اهميت هر متغير، يزوهشهايى را در سازمانهاى گَوناكون به منظور بررسى ميزان ارتباط

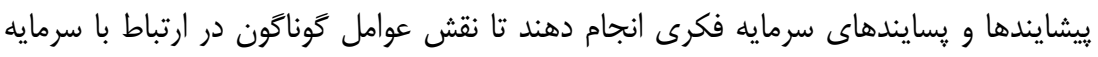

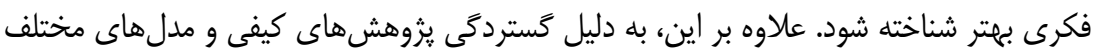

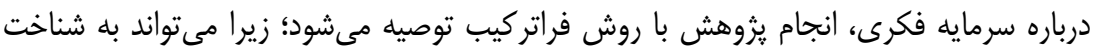

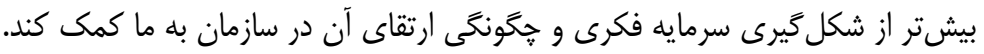

احمديان، مجيد، و قربانى، رحيمى (rqس (). بررسى رابطه بين سرمايه فكرى و عملكرد سازمانى: مورد مطالعه وزارت منابع الف) فارسى

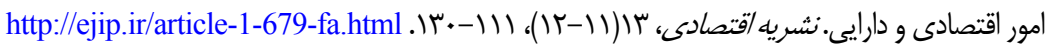

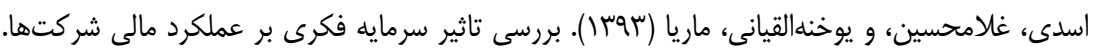

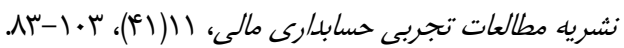

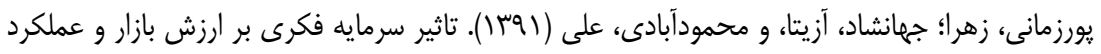

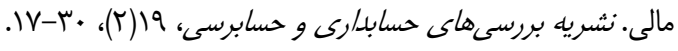

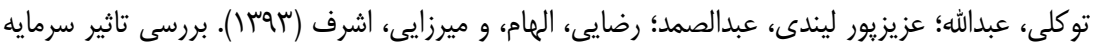

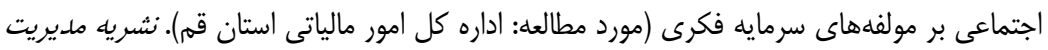

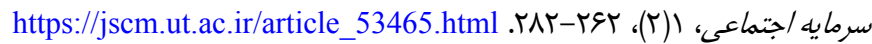

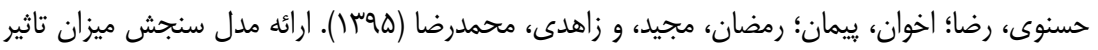

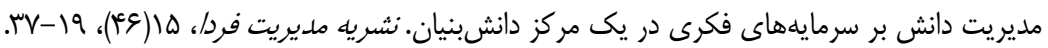

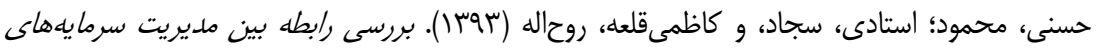

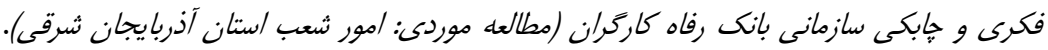

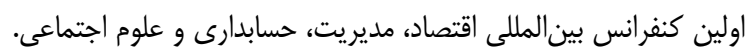

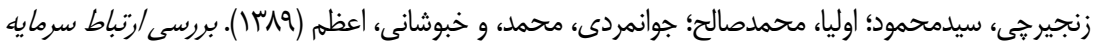

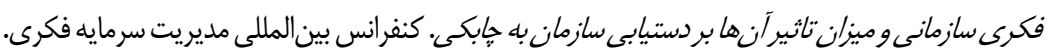

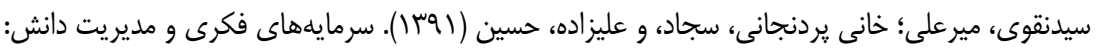

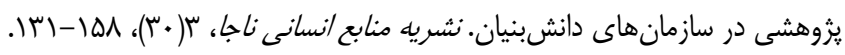

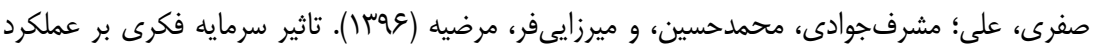

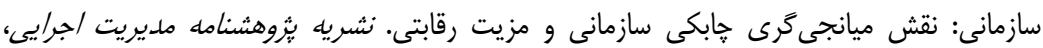

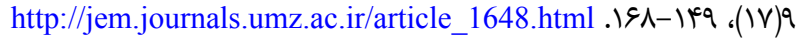

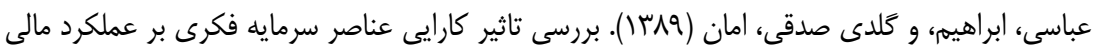

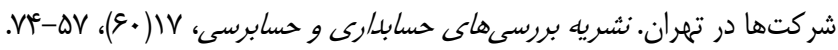




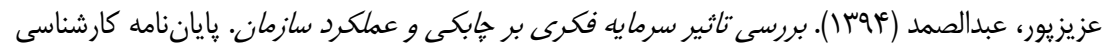

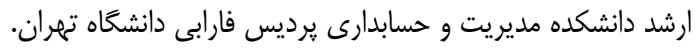

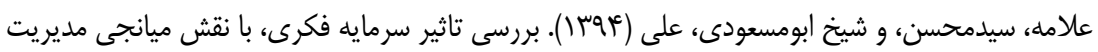

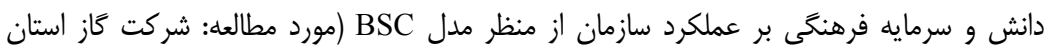

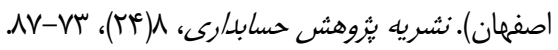

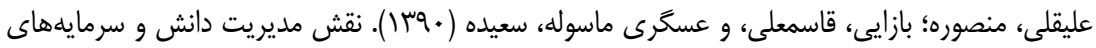

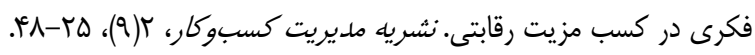

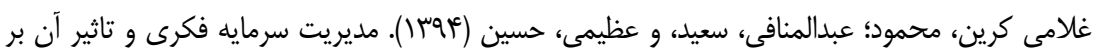

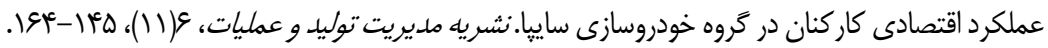

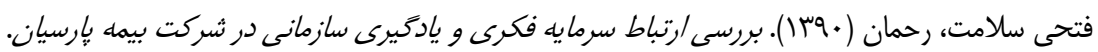

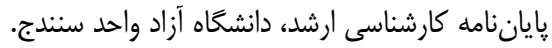

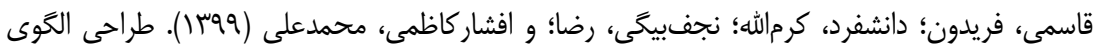

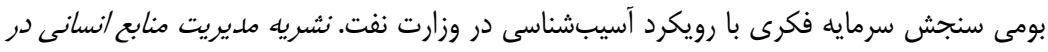

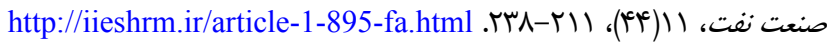

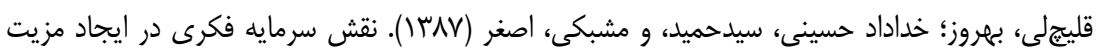

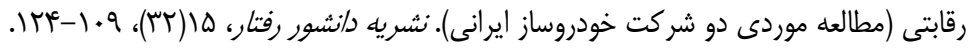

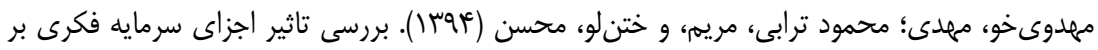

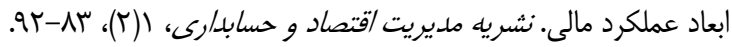

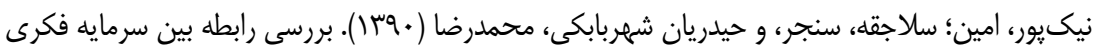

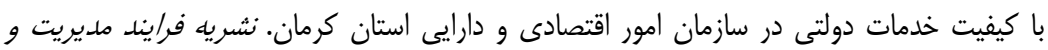

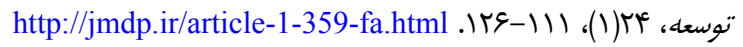

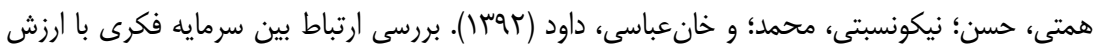

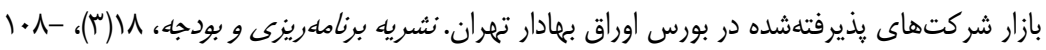
http://jpbud.ir/article-1-1072-fa.html .یv

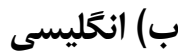

Bontis, N., Keow, W. C. C., \& Richardson, S. (2000). Intellectual Capital and Business Performance in Malaysian Industries. Journal of Intellectual Capital, 1(1), 85-100. https://doi.org/10.1108/14691930010324188

Brooking, A. (1996). Intellectual Capital: Core Asset for the Third Millenium Enterprise: International Thomson Business Press.

Campbell, B. A., Coff, R., \& Kryscynski, D. (2012). Rethinking Sustained Competitive Advantage from Human Capital. Academy of Management Review, 37(3), 376-395. https://doi.org/10.5465/amr.2010.0276 
Chen, M. C., Cheng, S. J., \& Hwang, Y. (2005). An Empirical Investigation of the Relationship between Intellectual Capital and Firms' Market Value and Financial Performance. Journal of Intellectual Capital, 6(2), 159-176. https://doi.org/10.1108/14691930510592771

Edvinsson, L., \& Malone, M. (1997). Realizing Your Company's True Value by Finding Its Hidden Brain Power. Intellectual Capital.

Flamholtz, E. G., Bullen, M. L., \& Hua, W. (2002). Human Resource Accounting: A Historical Perspective and Future Implications. Management Decision, 40(10), 947-954. https://doi.org/10.1108/00251740210452818

Ghafuri, P., Farhadi, A., \& Mansouri, A. (2014). Relationship between Intellectual Capital and Organizational Agility With Mediatory Role of Employee Empowering in Service Sector (Case Study: Karafarin Insurance Company). International Journal of Economy, Management and Social Sciences, 3(12), 11-15.

Gogan, L.-M., \& Draghici, A. (2013). A Model to Evaluate the Intellectual Capital. Procedia Technology, 9(1), 867-875.

Herremans, I. M., \& Isaac, R. G. (2004). The Intellectual Capital Realization Process (ICRP): An Application of the Resource-Based View of the Firm. Journal of Managerial Issues, 16(2), 217-231.

Hsu, I. C., \& Sabherwal, R. (2012). Relationship between Intellectual Capital and Knowledge Management: An Empirical Investigation. Decision Sciences, 43(3), 489-524. https://doi.org/10.1111/j.1540-5915.2012.00357.x

Indiyati, D. (2016). An Influence of Knowledge Management to the Intellectual Capital and the Effect to the Competitive Advantage. Sains Humanika, 8(12), 9-15. https://doi.org/10.11113/sh.v8n1-2.826

Johannessen, J.-A., Olsen, B., \& Olaisen, J. (2005). Intellectual Capital as a Holistic Management Philosophy: A Theoretical Perspective. International Journal of Information Management, 25(2), 151-171. https://doi.org/10.1016/j.ijinfomgt.2004.12.008

Kannan, G., \& Aulbur, W. G. (2004). Intellectual Capital: Measurement Effectiveness. Journal of Intellectual Capital, 5(3), 389-413. https://doi.org/10.1108/14691930410550363

Khalique, M., Nassir Shaari, J. A., Isa, A. H. b. M., \& Samad, N. (2013). Impact of Intellectual Capital on the Organizational Performance of Islamic Banking Sector in Malaysia. Asian Journal of Finance \& Accounting, 5(2), 75-83. http://dx.doi.org/10.2139/ssrn.2327407

Klaila, D., \& Hall, L. (2000). Using Intellectual Assets as a Success Strategy. Journal of Intellectual Capital, 1(1), 47-53. https://doi.org/10.1108/14691930010324133

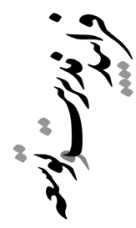


Komnenic, B., \& Pokrajčić, D. (2012). Intellectual Capital and Corporate Performance of MNCs in Serbia. Journal of Intellectual Capital, 13(1), 106-119. https://doi.org/10.1108/14691931211196231

Leliaert, P. J., Candries, W., \& Tilmans, R. (2003). Identifying and Managing IC: A New Classification. Journal of Intellectual Capital, 4(2), 202-214. https://doi.org/10.1108/14691930310472820

Lin, C. Y.-Y., \& Edvinsson, L. (2010). National Intellectual Capital: A Comparison of 40 Countries: Springer Science \& Business Media.

Litschka, M., Markom, A., \& Schunder, S. (2006). Measuring and Analysing Intellectual Assets: An Integrative Approach. Journal of Intellectual Capital, 7(2), 160-173. https://doi.org/10.1108/14691930610661836

Martín-de Castro, G., \& Verde, M. D. (2012). Assessing Knowledge Assets in Technology-Intensive Firms: Proposing a Model of Intellectual Capital. Journal of CENTRUM Cathedra: The Business and Economics Research Journal, 5(1), 43-59. https://ssrn.com/abstract=2018399

Martínez-Torres, M. R. (2006). A Procedure to Design a Structural and Measurement Model of Intellectual Capital: An Exploratory Study. Information \& Management, 43(5), 617-626. https://doi.org/10.1016/j.im.2006.03.002

Mention, A. L., \& Bontis, N. (2013). Intellectual Capital and Performance Within the Banking Sector of Luxembourg and Belgium. Journal of Intellectual Capital, 14(2), 286-309. https://doi.org/10.1108/14691931311323896

Moon, Y. J., \& Kym, H. G. (2006). A Model for the Value of Intellectual Capital. Canadian Journal of Administrative Sciences/Revue Canadienne des Sciences de l'Administration, 23(3), 253-269. https://doi.org/10.1111/j.1936-4490.2006.tb00630.x

Mouritsen, J. (2004). Measuring and Intervening: How Do We Theorise Intellectual Capital Management? Journal of Intellectual Capital, 5(2), 257-267. https://doi.org/10.1108/14691930410533687

Mulyatini, N., Sumantri, S., \& Narimawati, U. (2019). Model of Intellectual Capital and Locus of Control on the Performance of Public Sector Internal Auditors through Professional Commitment.Journal of Management Review, 3(2), 333-343. http://dx.doi.org/10.25157/mr.v3i2.2615

Organisation for Economic Cooperation and Development (1999). The Knowledge-Based Economy: A Set of Facts and Figures. Meeting of the Committee for Scientific and Technological Policy at Ministerial Level, Paris.

Pigott, T. (2012). Advances in Meta-Analysis: Springer Science \& Business Media.

Roos, G., \& Roos, J. (1997). Measuring Your Company's Intellectual Performance. Long Range Planning, 30(3), 413-426. 
https://doi.org/10.1016/S0024-6301(97)90260-0

Roos, J., Edvinsson, L., \& Dragonetti, N. C. (1997). Intellectual Capital: Navigating the New Business Landscape: Springer.

Sackmann, S. A., Flamholtz, E. G., \& Bullen, M. L. (1989). Human Resource Accounting: A State of the Art Review. Journal of Accounting Literature, $8(12), 235-264$.

Schultz, T. W. (1961). Investment in Human Capital. The American Economic Review, 51(1), 1-17.

Seleim, A., Ashour, A., \& Bontis, N. (2007). Human Capital and Organizational Performance: A Study of Egyptian Software Companies. Management Decision, 45(4), 789-801. https://doi.org/10.1108/00251740710746033

Shih, K. H., Chang, C. J., \& Lin, B. (2010). Assessing Knowledge Creation and Intellectual Capital in Banking Industry. Journal of Intellectual Capital, 11(1), 74-89. https://doi.org/10.1108/14691931011013343

Stewart, T. A. (1991). Brainpower. Fortune Magazin. http://money.cnn.com

Stewart, T. A. (2010). Intellectual Capital: The New Wealth of Organization: Currency.

Stewart, T., \& Capital, I. (1997). The New Wealth of Organizations: Nicholas Brealey.

Sveiby, K. E. (1997). The New Organizational Wealth: Managing \& Measuring Knowledge-Based Assets: Berrett-Koehler Publishers.

Ulrich, D. (1998). Intellectual Capital= Competence x Commitment. MIT Sloan Management Review, 39(2), 15-26.

Usoff, C. A., Thibodeau, J. C., \& Burnaby, P. (2002). The Importance of Intellectual Capital and Its Effect on Performance Measurement Systems. Managerial Auditing Journal, 17(1/2), 9-15. https://doi.org/10.1108/02686900210412180

Wang, Z., Wang, N., \& Liang, H. (2014). Knowledge Sharing, Intellectual Capital and Firm Performance. Management Decision, 52(2), 230-258. https://doi.org/10.1108/MD-02-2013-0064

Wernerfelt, B. (1984). A Resource-Based View of the Firm. Strategic Management Journal, 5(2), 171-180. https://doi.org/10.1002/smj.4250050207

Zhou, A. Z., \& Fink, D. (2003). Knowledge Management and Intellectual Capital: An Empirical Examination of Current Practice in Australia. Knowledge Management Research \& Practice, 1(2), 86-94. https://doi.org/10.1057/palgrave.kmrp.8500009 